\title{
INTERVENTION IN VERNACULAR ARCHITECTURE: THE LESSON OF FERNANDO TÁVORA
}

\author{
D. Ordóñez-Castañón ${ }^{1, *}$, T. Cunha-Ferreira ${ }^{2}$, S. Sánchez-Beitia ${ }^{1}$ \\ ${ }^{1}$ School of Architecture, University of the Basque Country (UPV/EHU), Donostia / San Sebastián, Spain - (david.ordonez, \\ santiago.sanchez)@ehu.eus \\ ${ }^{2}$ Centre for Studies in Architecture and Urbanism, Faculty of Architecture of the University of Porto (FAUP) - tferreira@arq.up.pt
}

KEYWORDS: Fernando Távora, Vernacular Architecture, Modernism, Heritage Renovation, Adaptive Reuse, Intervention Criteria

\begin{abstract}
:
This article seeks to analyse the methodology and principles underlying the interventions of the Portuguese architect and professor Fernando Távora (1923-2005) in the conservation and renovation of vernacular architecture in the north of Portugal. The publication of his essay O problema da Casa Portuguesa (1945), his attendance at the last CIAM meetings (1952-1959) and his participation in the Survey on Popular Architecture in Portugal (1956-1961) reaffirmed his belief in creating a modern architecture that respected the values of local traditions. The features of the so-called "third way" - building a bridge between tradition and modernity - are to be found not only in his ex novo works, but also in his conservation and renovation of rural constructions, such as the house of Quinta da Cavada in Briteiros (1989-90) and another house in Pardelhas (1993-99). Based on the evidence of these case studies, this paper will focus on the features of his particular modus operandi: a case-by-case approach, a deep knowledge of vernacular constructions, the recovery of traditional materials and techniques supported by the ancestral knowledge of local craftsmen, respect for the preexisting scale through the use of 'anonymous design' and 'subtle modernity', visible in such gestures as the colour treatment, furniture design, joinery, light fixtures, door handles or metalwork. Finally, the paper will also reflect on the importance of Távora's teachings about interventions in vernacular architecture in Portugal, as well as on the future challenges for the preservation of this scattered heritage in the light of the current abandonment and depopulation of rural areas.
\end{abstract}

\section{INTRODUCTION}

Due to the deep social and agricultural changes that have affected the countryside in recent decades, the Portuguese vernacular architectural heritage is in a state of serious vulnerability. The abandonment of crops and the mechanisation of farms have led to the dysfunction of many rural constructions. Farmhouses, granaries, barns... are buildings that have left a powerful imprint on the landscape, while also playing an important role in the collective memory and cultural identity of rural societies. However, some of them have been abandoned or have been subjected to inadequate transformations. The adaptive reuse of farmhouses is a feasible alternative for prolonging the life of these constructions since there are many possibilities for their functional conversion. Nevertheless, the reoccupation of ruined architectures is not always simple because an in-depth transformation is required to adapt them to the needs of contemporary lifestyles, incorporating the latest functional advances and the improvements in comfort. Hence, many renovations have not respected the historical and architectural values of pre-existing buildings.

The career of the Portuguese architect and professor Fernando Távora (the mentor of Álvaro Siza and Eduardo Souto Moura, among other architects from the Porto School) was closely linked to his interventions in the architectural heritage. Some of his most valuable refurbishments were renovations of rural houses. These examples show an effective adaptation of spaces and forms to a new programme of uses while preserving the memory of the pre-existing building and its strong identity in the landscape. Thus, the aim of this paper is to define the patterns of Távora's conservation and renovation design methodology when modernising vernacular architecture.
Távora displayed great sensitivity to vernacular constructions, as well as having a profound knowledge of rural culture:

Távora travelled through the rural world, reconstituting the colours and smells (...). He carefully observed the ingenuity and art of our Minho people in the construction of their houses, granaries and tanks. He realised how humans and animals lived, in perfect harmony, at the zero level of survival. He smelled stables and crops, breathed fireplaces with smoke and imbibed harsh reds, observed the work in the fields, the oxen and the hoes, the channelling of water for irrigation, the crystal clear rivers without industry, the cornfields, the vegetable gardens, the vineyards and the orchards (...) (Costa, 2005).

Távora was therefore familiar with the characteristics of smallholdings scattered throughout northern Portugal (known in Portuguese as casas de lavoura minhotas). These farmhouses were composed both of areas that were used for domestic functions and of a set of spaces designed for agricultural activities, constituting a self-sufficient productive unit. In addition, this architectural typology is generally defined by its privileged setting in the landscape: enjoying a favourable relationship with natural elements (sun, water, wind), good bioclimatic conditions (passive energy, good thermal inertia in the walls) and an optimised functional distribution (the animals were generally kept on the ground floor in order to heat the upper floor for human functions; a big kitchen with a fireplace became the main common living space of the house, while the other rooms were small), among other characteristics (Sindicato Nacional dos Arquitectos, 1962).

* Corresponding author 


\section{BACKGROUND: DEVELOPMENT OF THE "THIRD WAY" IN PORTUGAL}

The scientific study of the popular traditions of the rural areas of Portugal began at the end of the nineteenth century in an attempt to justify the nationalist spirit of the urban elite. Ethnographers, musicologists, anthropologists, and many others besides, undertook field research in the most remote villages, seeking to characterise a genuinely Portuguese culture (Leal, 2009). Interest soon grew in discovering the features of an "authentically national" architecture, giving rise to the "Portuguese House" movement, led by the architect Raúl Lino and supported by the dictatorship (which, at the same time, blocked the development of modern architecture).

In the manifesto $O$ problema da casa portuguesa, Fernando Távora criticised this trend of taking certain features from tradition and using them in a merely decorative way. Instead, he advocated a detailed study of popular architecture, from which valuable lessons could be drawn "because it is more functional and less fanciful" (Távora, 1945). This request flourished years later with the Inquérito (Survey on Popular Architecture, 19561961). This research was a large-scale programme organised by the Union of Portuguese Architects and conducted by some of the most renowned architects from Porto and Lisbon. The peninsular territory was divided into six zones, one of which, the Minho region (in the north of Portugal), was coordinated by Fernando Távora, who, in collaboration with other architects, undertook an enormous amount of fieldwork in order to catalogue Portuguese vernacular architecture (Figure 1). The success of the book Popular Architecture in Portugal (Sindicato Nacional dos Arquitectos, 1961), published as a direct result of the Surveys, led to the reuse and reinterpretation of traditional construction systems in the work of most Portuguese architects, seeking to show that there was not just one single national and stereotyped style of architecture defended by the dictatorial regime, but, instead, several expressions depending on the specificities of each region. Moreover, the Surveys were intended to demonstrate the affinity between the vernacular and the modernist values of pragmatism, functionality and truthful tectonics (Fernandes, 2019).

The proposal for a "third way" (bridging tradition and modernity) found international support in the revisionist context of the modern orthodoxy of the 1950s. Távora's attendance to some of the latest CIAMs (International Congresses of Modern Architecture) made him aware of the change in direction taken by the European architectural avant-garde. The youngest attendees of these congresses, the founders of Team X, advocated a return to considering the specific conditions of each particular (cultural, historical, geographical, climatic, etc.) context. Távora was also able to interact with other colleagues, who were similarly interested in issues relating to contemporary creation in a historical context, such as E.N. Rogers. Numerous reflections by the Italian theorist on the need to establish continuity between personal creation and the presence of tradition left a powerful mark on the Portuguese architect.

The genuine modernity of Brazilian architects also had a decisive influence on the progress of modern architecture in Portugal, duly adapted to its own regional singularities. Brazilian modernism was thus able to establish a close link with the preexisting cultural tradition through the creative reinterpretation of elements and materials taken from popular construction, such as brise-soleil, cobogós, latticework or tile mosaics. These influences arrived in Portugal through the catalogue of the exhibition Brazil Builds: architecture new and old, 1652-1943, shown at MoMA (Goodwin, 1943). The theories (especially the essay Documentação Necessária), research and renovation work of Lucio Costa (such as the Museu das Missões, 1940), as well as his excursions through rural areas in Portugal may have influenced Távora's approach to heritage intervention as well.
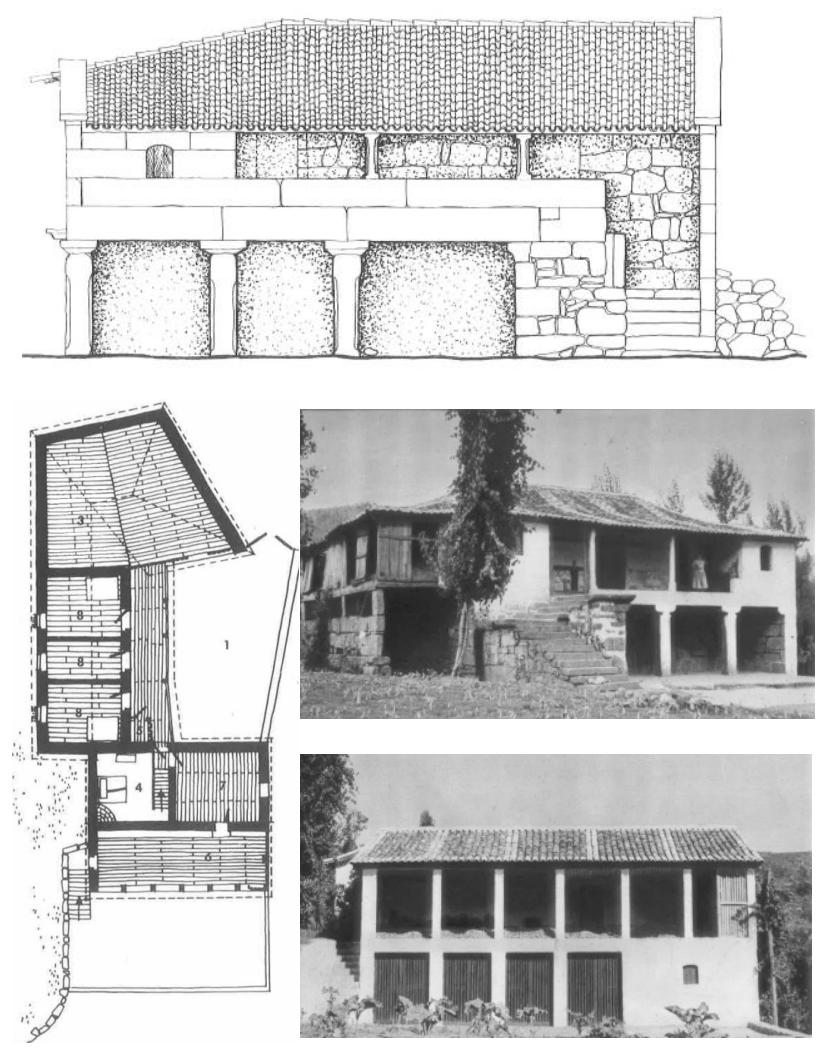

Figure 1. Elevation, plan and pictures of typical granite farmhouses (casa de lavoura minhota) in the Minho region (Popular Architecture in Portugal, 1961).

This new sensitivity to tectonic and vernacular traditions was reflected in works such as the tennis pavilion at the Quinta da Conceição and the Casa em Ofir (1956). No less important, however was the proposal for an innovative approach to interventions in the historical heritage. The relationship between "new" and "old", a question that was raised by Távora, began to move away from the traditional dichotomy between the Romantic principles of non-intervention and stylistic restorations. Until then, the prevailing practice in Portugal, strongly conditioned by the nationalist ideology of the Estado Novo, through the Direção-Geral dos Edificios e Monumentos Nacionais (DGEMN - Directorate-General of National Buildings and Monuments) had, generally speaking, aimed at the stylistic restoration of idealised primitive forms in the monument (Ferreira, 2007).

Távora also defended a new conception of the "monument", with the aim of "going beyond this or that more or less erudite building, of more or less known history, to encompass vaster environments and more humble buildings" (Távora, 1964). He also pointed out that "the work of the past is a cultural value of space and, [...] since this is irreversible, it cannot again be, or continue being, what it already was, so it should not be updated through the use of "pastiche". In his opinion, mimesis was a solution that "only manifests the inability to find another style that, due to its contemporary nature, can be compared - without obfuscating or being obfuscated- to the value that the past bequeathed us" (Távora, 1964). 
In this way, Távora forged a new approach to heritage intervention methodology and criteria in Portugal. His personal modus operandi first became visible at the end of the 1950 s, at his mother-in-law's Casa do Além (1956-67), being repeated, shortly afterwards, in the refurbishment of the Casa da Igreja and later developed in other renovations with powerful pedagogical repercussions in the Portuguese context (OrdóñezCastañón et al., 2019). The expansion of the Pousada de Santa Marinha da Costa (1972-1985), the Escola Superior Agrária de Refóios do Lima (1987-1993) and the Casa da Rua Nova (19851987) are other important examples. According to Távora's statement about the project for the Santa Marinha da Costa Monastery:

The general criterion [...] was 'to continue innovating' or, in other words, to continue contributing to the long life of the building, by conserving and strengthening its most significant spaces or creating qualified spaces determined by the conditions of their new function. The intention was to create a dialogue, highlighting the affinities and the continuity, rather than the differences and the break from the past (Távora, 1985).

\section{RESEARCH METHODOLOGY}

The research methodology is based on bibliographical and, above all, archival research, conducted mainly into Fernando Távora's personal archive, which is housed at the Marques da Silva Foundation Institute (FIMS) in Porto. It is composed of over three hundred architectural and urban planning projects, a significant number of which (around seventy) correspond to renovation interventions in pre-existing buildings. This archive also comprises his personal library, composed of more than six thousand volumes, covering multiple subjects in different languages (including traditional architecture, the history of architecture and human geography, among others) and revealing the profound cultural knowledge of the architect. Besides his architectural drawings, FIMS also preserves many photographs, personal notebooks, travel sketches, models, executive documents, budget estimations, letters, etc.

The study of the archival documentation was further complemented by field research, involving direct observation of the works (systematic photographic surveys, drawings and notes), as well as by interviews both with the buildings' owners and with Távora's collaborators who were directly involved in each specific project. Furthermore, the works were analysed and interpreted, using drawing as a research tool (geometrical studies, yellow-red colour survey, constructive details, etc.).

After a primary analysis of several interventions by Távora in rural vernacular houses in northern Portugal, two case studies were selected due to their greater representativeness. Despite certain circumstantial differences, both works possess the main features that can be defined as representative of Távora's approach to this type of buildings. Files kept in the archive (sketches, preliminary designs, execution projects, correspondence, bureaucratic details, etc.) were analysed in depth. However, given the vernacular nature of these constructions, there is almost no historical or photographic documentation and, in keeping with Távora's method, there is also only limited documentation of the project. Although the two case studies were projects that had been little studied previously, in recent years they have been analysed in detail in some academic works that were also consulted (Alves, 2019; Cotter, 2013; Mourão, 2013).
For the purpose of comparative analysis and discussion, the selected case studies were dissected according to four predefined parameters: 1) Firstly, the description of the preexisting building, namely the aspects relating to its cultural context (historical, geographical, agro-productive, landscape, etc.), as well as its state of conservation prior to the intervention. 2) Secondly, the design strategy for adapting the pre-existing building to new uses, as well as for preservation and/or transformation operations. 3) The relationship between new and old, especially at their points of contact, and the mechanisms of interaction (mimesis, contrast, continuity, abstraction...). 4) Tectonic and constructive features, also related with the choice of materials and techniques, finishing details, furniture and decoration. At a subsequent stage, through the comparative analysis of the case studies, some diverging nuances and common patterns are identified, with the purpose of defining Fernando Távora's design principles for the renovation of rural houses.

\section{CASE STUDIES}

The proposed case studies, namely the renovation of Quinta da Cavada in Briteiros (1989-1990) and of a house in Pardelhas (1993-1999), constitute a representative sample summarising the architect's design strategies when intervening in pre-existing rural buildings. Both projects belong to the author's mature stage, when his methodological procedures relating to the relationship between old and new were fully defined. By this point in time, Fernando Távora had already developed an absolutely personal intervention methodology, which is clearly expressed in both examples.

We can, however, observe the evolution and consolidation of Távora's methodology and approach towards vernacular heritage in other previous works. The renovation of the Casa do Além (1956-1967) can be regarded as a precursor of his later work, since he anticipated here some design guidelines that were subsequently applied in Briteiros and Pardelhas. This early work coincides with a period of extraordinary conceptual density and professional production on the part of the architect, who, at that time, focused his attention on combining the expressiveness of modern forms with a respect for local identities and traditions. This concern is reflected here, as he preserved the materiality and identity of the vernacular building while simultaneously introducing innovative new door and window frames with a single large pane of glass, simplified forms and a striking red colour.

However, these cases were not the only interventions by Távora in the countryside. Although manor houses have some different characteristics (a larger size, erudite language, representative character, etc.), they were also part of the same agricultural system and constructive tradition. Fernando Távora's numerous renovation projects for stately homes thus display similar design strategies. Therefore, like the Casa do Além, the Casa da Igreja in Mondim de Basto can be considered a seminal attempt to apply his principles of heritage intervention, as well as a paradigmatic case of the "third way". While, in these two cases, Távora expressively assumes the contemporaneity of new elements (window frames, balcony), in the later cases of Pardelhas and Briteiros (as we shall see) the modernity is more subtle in the design of some details. Experimental approaches were later matured in other manor house renovation projects, such as the one for the Casa da Covilhã (1963-1988) and the one for the Casa da Breia (19841985), besides other proposals that were never implemented. The analysis of Távora's interventions in these old mansions 
reveals that he adopted a case-by-case approach, rejecting the application of predetermined or axiomatic principles for heritage intervention. It can be noted that his conservation and renovation design methodology was based, on the one hand, on a rigorous preservation of elements that have greater architectural value and symbolic importance, such as the main façades and social reception rooms. On the other hand, those parts of the building that have a lower architectural value may be carefully altered to incorporate new functions and update the building's image through a creative reinterpretation of the constructive tradition. Although some differences can be found, nevertheless, some of these conclusions may also be extrapolated to the case studies, which are analysed below.

\subsection{Renovation of the Casa da Quinta da Cavada (Briteiros, 1989-1990)}

This country house, located in the municipality of San Salvador de Briteiros (on the outskirts of Guimarães), was formerly owned by a nearby manor house (the Casa da Ponte) and was inhabited by settlers who worked the land of the lord of the manor. It is a solid granite construction, nestling peacefully on the hillside and well-oriented in terms of the weather: it is organised around a sunny courtyard, onto which most of the windows open, and protected from the cold winds from the north by an almost windowless masonry wall. This complex, which was successively expanded in accordance with the demands of rural life, finally adopted a two-storey L-shape, with the living quarters in the building's shorter wing and the areas dedicated to livestock and crop drying situated along the longer side. The two parts were connected by an intermediate volume used for the storage of agricultural implements.

Progressively, the fields ceased to be cultivated and/or industrialised farming techniques were introduced, so that this farmhouse lost its usefulness as a productive complex, ending up being abandoned. At the end of the 1980s, Maria Luísa Guimarães and her husband bought the property to satisfy their wish to refurbish an old house in the countryside where they could spend their holidays with their family. The building was severely damaged when they purchased it: part of the roof had collapsed (especially in the area of the present-day living-room) and the wooden structure was also in serious danger of collapsing. However, the thick granite walls had stood firm and the identity and legibility of all the building's forms and spaces remained unaltered.

After visiting the ruin, Távora could see the enormous potential of the pre-existing building, so that "this work became a toy for him" $"$ and he greatly enjoyed putting his knowledge and theories into practice. A relationship of friendship and trust developed between the architect and the client, which extended to the labourers who worked there. Távora began the design process by thoroughly studying the history of the pre-existing building. In his own words, "the most important thing about this project was to perceive the history there and give it the respect it deserved" (Távora, 1990). In the absence of any ancient documents, this was done through an attentive reading of the joints and "scars" that the building showed, and supported by the deep knowledge that he had about the history of the Portuguese countryside. In fact, he considered this to be a "sacred" place, as it had been farmed since very ancient times. The house stands on the edge of Citánia de Briteiros, a

Interview with Maria Luísa Guimarães (owner of the building and promoter of the renovation project), while visiting the Quinta da Cavada (10/23/2018). village of Celtic and Roman origin (Távora, 1993). This area suffered a number of raids by Muslim forces and gradually became pacified as the Middle Ages advanced. The revolutionary introduction of corn during the seventeenth and eighteenth centuries led to the successive extensions of the house in order to accommodate the increased productivity. Távora assumed that his elementary stratigraphic study "cannot guarantee the [absolute] chronology of the building, but it can guarantee the different phases in which it was constructed" (Távora, 1990).

His interpretation was portrayed a posteriori in a drawing that showed the growth of the building, with his own intervention being introduced as yet another historic phase (Figure 2). The original core of the building was "just a hut to colonise the territory"; it housed the wine press on the ground floor, plus a kitchen and a room on the first floor. The veranda was added on the south side of the building in a subsequent phase (Figure 3). This was a valuable covered space in which numerous domestic tasks could be performed, with the advantage of protecting the interior from severe weather in winter and from the hot sun in summer. Later, with the planting of corn, a separate rectangular block was built, containing three stables on the ground floor, with a large barn on the upper floor. The sequeiro was a large open space facing east, closed on this same side by a permeable wooden fence. In a later phase, the front door was added and the intermediate section joining the two constructions together was built (as a chamfered extension of both volumes), creating the backyard (eido). This space functions as a private outdoor space, an "outdoor room" that supports agricultural activities and can be used for both domestic and productive purposes.
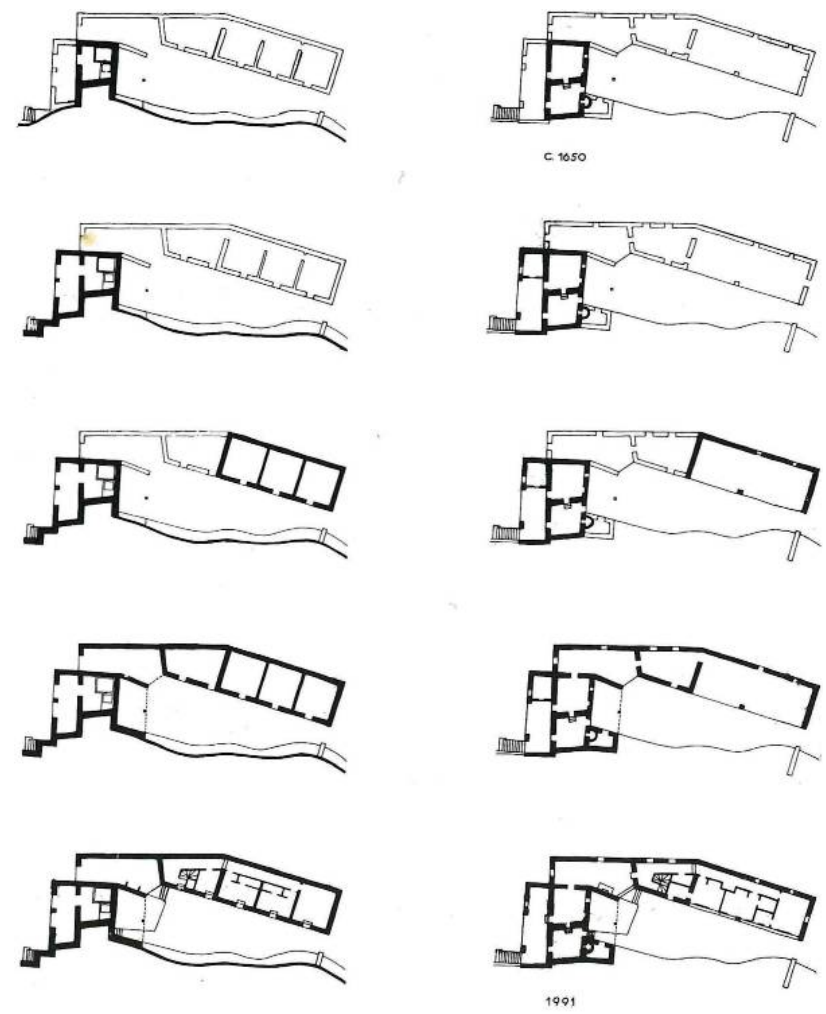

Figure 2. Growth of the building from c. 1650 to 1991 (left: ground floor; right: first floor), including Távora's intervention as the last stage. (FIMS/FT/0260-01-0003). 
Távora therefore accepted that the functional reconversion of the building would be an appropriate formula for preserving its original values. With this in mind, he devised some modern solutions which, nevertheless, evoked memories of the house's previous image. Thus, the light wall facing the patio (composed of windows alternating with a series of vertical slats) evokes the permeable wooden fence of the old sequeiro (Figure 4). Furthermore, the doors of the stables retained their traditional appearance, since they were made in accordance with a model typically found in the popular architecture of Guimarães.

In functional terms, the building's original core retained the kitchen (albeit renovated) and the adjoining dining room, while the connecting space was transformed into a living room. The stables were converted into bedrooms and the spacious barn was partitioned in order to introduce additional bedrooms and bathrooms. On both floors, the rooms overlook the backyard in order to capture both sunlight and heat, while the new corridor runs along the inside of the blind wall, in order to protect the rooms from the cold north wind. A newly-built staircase connects the two floors and serves as a lobby between the living room and the privacy of the bedroom area.

In general, a conservative criterion was followed for the preservation of structural elements, including the doors, joinery and metalwork, in addition to other features. In fact, when the roof was repaired, the replacement tiles were brought from a demolished building, so as not to alter the colour. However, this respectful attitude did not completely constrain the architect, who acted freely when he decided to knock down some walls in order to make new openings. These operations were carried out spontaneously, without making use of the differentiated language established by international restoration guidelines. Nevertheless, the apparent anonymity of the intervention is not at odds with the incorporation of new elements that display a discreet modernity: the large windows of the upper bedrooms and, above all, the picture window of the living room express a subtle sophistication with their stylised white-painted frames. Likewise, the parasols of the veranda, the kitchen furniture and the simplified banister of the new staircase all reflect a design that is based on the abstraction of traditional elements. In this silent intermingling of old and new features, it is the skilful use of colour that serves as a unifying strategy. The two-tone finish of the building's light elements (white for the eaves and the joinery and blood red for the surfaces of the fencing, railings, parasols, etc.) gives a unitary and renewed appearance. Similarly, white is the predominant colour of the interior surfaces (Figure 5), softening the rough appearance of the exposed stone and generating a homogeneous and light-filled atmosphere that previously was non-existent.

As Távora points out, "the development of the project was unorthodox, in the sense that, once the first sketches had been made, the execution was undertaken without the need for plans" (Távora, 1993). Most of the architect's work took place at the construction site, giving the appropriate instructions to workers in a similar way as a master builder would have done centuries ago. In the absence of plans, visits to the site were constant and all unforeseen events were resolved spontaneously, with drawings being made on the wall or on any surface within reach. In fact, the documents that had to be submitted compulsorily to the town hall resulted from a subsequent survey, which was unofficially compiled at the architect's studio. This apparent improvisation was based on trust and the good understanding between Távora and the labourers, who, like him, mastered the traditional construction techniques.

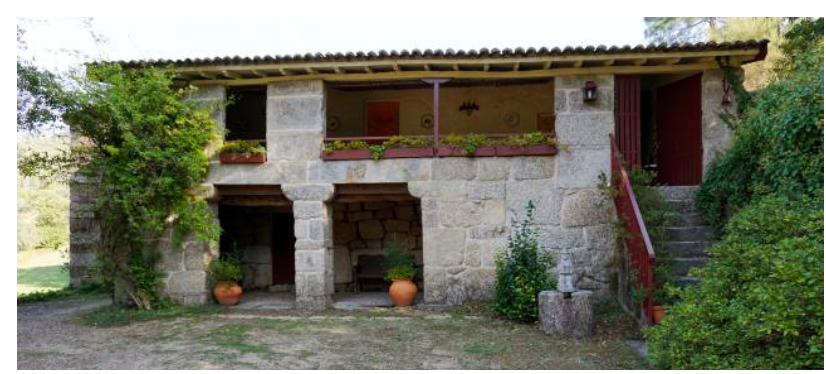

Figure 3. View of the west façade.

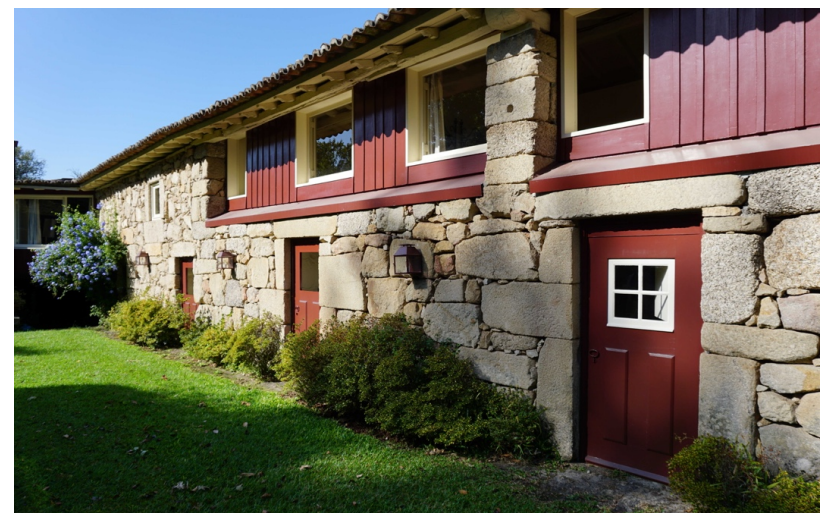

Figure 4. Façade facing the backyard.

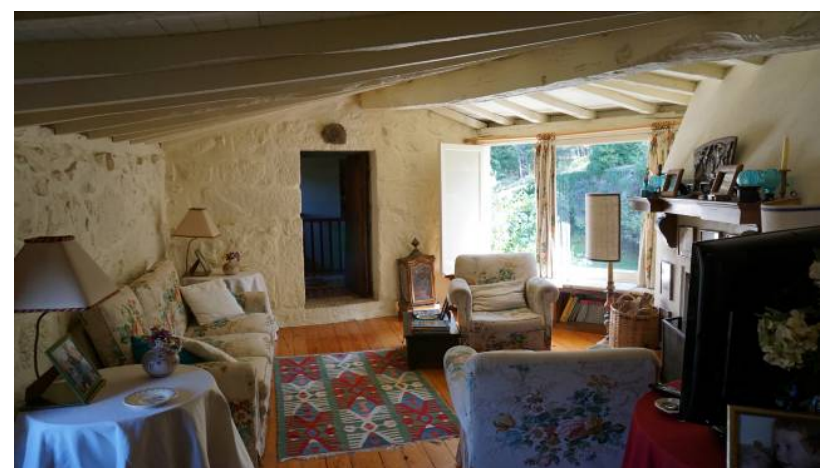

Figure 5. Sitting room.

\subsection{Renovation of a House in Pardelhas (1993-1999)}

Pardelhas is a small hamlet located in the north of Portugal, close to the border with Spain (separated by the River Minho), in an area of transition between the rugged mountains and the cultivated farmland below. Here we can find a rural complex composed of a series of architectural pieces that Távora refurbished in the 1990s. The main house is an L-shaped granite construction flanked on two of its sides by other buildings of a similar type, from which it is separated by dividing walls. Because of its introverted arrangement, the house receives sunlight and heat from the south and is protected against the inclement weather that comes from the northwest. Thus, the rooms face, through the veranda, towards the courtyard, which is accessed through a narrow alley. Only one side of the house has views over the wonderful landscape. However, after passing under the archway of the bridge/building, we discover a large estate that spreads out from the foot of the house. The former farming estate is divided into five terraces that run in steps down the gentle slope. This land is mainly used as a garden and houses the Casa da Eira, the espigueiro (granary) and other auxiliary buildings (Figure 6). 


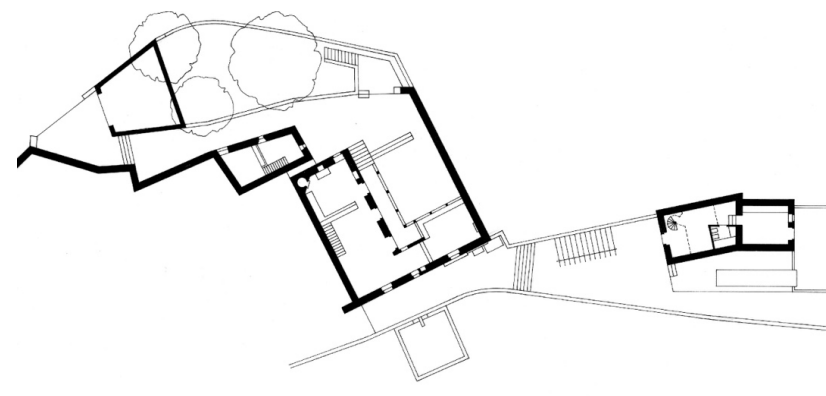

Figure 6. First floor plan. (FIMS/FT/0282-pd0001).

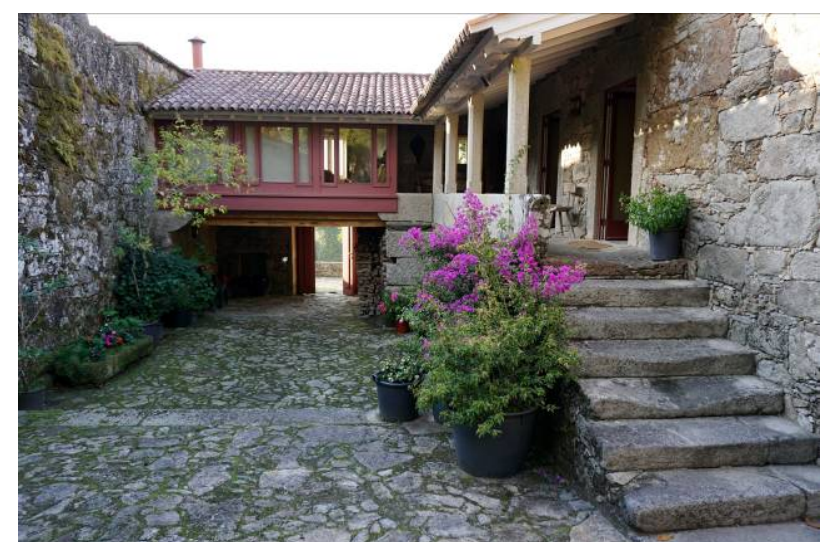

Figure 7. Veranda and glazed porch facing the courtyard.

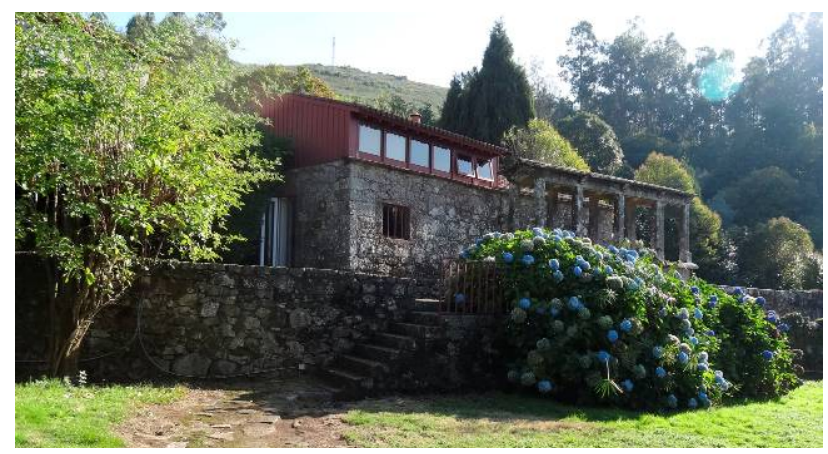

Figure 8. Casa da Eira.

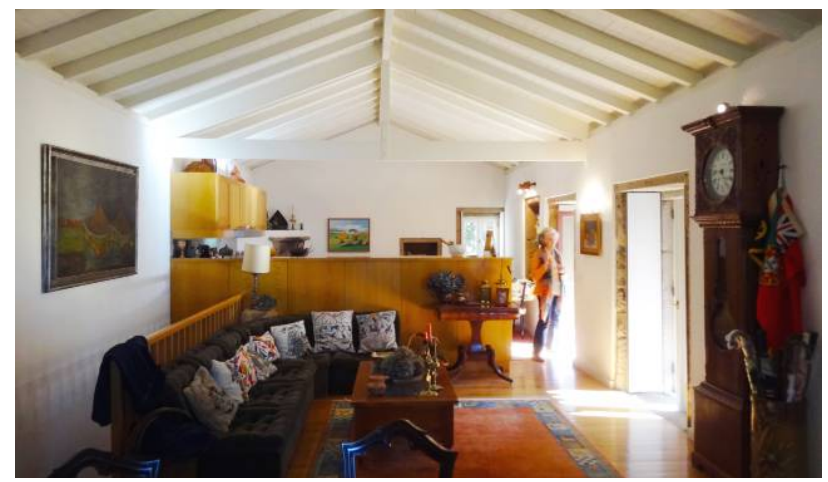

Figure 9. First floor: open-space kitchen and sitting room.

When the current owner of the house, Dr. Torres, acquired the property, it was already in a state of advanced ruin. The wooden roof and floor had already collapsed, and so a major operation was required to restore the building's structural stability and, after that, to improve its inhabitability and comfort. Távora and Dr. Torres had known each other since they were children. They belonged to a group of friends who used to frequent the same antiques shop in Guimarães. They shared a passion for collecting and both had a vast knowledge of history and art. Their erudition and intellectual affinity can be noted in the conceptual density of the operation, in the house itself and in the garden, too, where, as in the Quinta da Conceição, various sculptural elements evoke the memory of ancient constructions.

Távora immediately understood that the most important value of the house was its setting and its harmonious relationship with the landscape. His basic premise was to maintain the building's authenticity, which derived not only from its spatial and architectural structure, but also from the signs that show the passage of time: the wearing away of the steps, the moss on the stone, the open joints... Távora insisted on conserving the entire patina of the building, not only in order to preserve the beauty of its cheerfully kaleidoscopic colouring, but also to capture the poetics of the elapsed time. Water was the other element that he considered to be a vivid expression of the genius loci, so he asked if the system of reservoirs and canals that run through the estate could be reactivated. He was sure that water and moss had to be encouraged, if the house were to retain its essence and its sense of belonging to the place ${ }^{2}$.

The architect's sensitivity towards the pre-existing building called for great care in performing large-scale delicate works almost without touching the exterior walls. This careful manipulation was only possible thanks to the interest of the local builders, a father and his son, both of whom were experts in traditional construction techniques and took on the challenge of working in this singular way for a prestigious architect. They rebuilt the roof according to the traditional system (wood and tiles) and, in fact, recovered a number of region-specific solutions (tiles placed on slate eaves). Likewise, the missing granite supports of the veranda and its roof were replaced. Furthermore, the wooden structure of the sitting room (situated above the passageway leading to the estate) was rebuilt, in accordance with the traces that still remained from the previous construction. Thus, new wooden beams were inserted into the existing putlog holes and corbels. The floor of the rest of the building, however, was built in reinforced concrete in order to reduce its thickness and structurally consolidate the master walls. In Pedro Pacheco's words, this house was "a good ruin (...), it was almost like reading a text in which some words were missing and the correct words had to be inserted so that the text became legible and made sense" (Cotter, 2013).

Indeed, the aim of Távora's design was "to replace the missing pieces so that the building could work again". Consequently, there was no need to "invent" any solution, but simply to complete what was missing and to improve the building's hygrothermal performance. However, although the exterior image showed great creative restraint, the inserted elements could not be a copy of the previous ones (whose appearance was unknown), but the result of a formal debugging process. In the case of the missing upper columns of the veranda, Távora refined the design of the pillars that had been preserved on the lower floor and had them sculpted by a stonemason. As for the windows of the glazed porch, special care was taken to maintain a rhythm that offered a harmonious continuity with the pillars of the veranda (Figure 7). However, both the stylised frames and the large glazed surfaces are clear gestures of a modern design. In this sense, the architect Fernando Barroso states: "We ordered custom-made metalwork because the pieces we wanted did not exist in the market. They do not imitate the ancients, but they are not completely oblivious to

2 Interview with Pedro Pacheco (10/30/2019), the architect who worked on the development of the project. 
tradition either. In fact, all the joinery was manufactured according to traditional processes, but we were looking for the freshness of what is new and is not intended to blend in with the old" 3

Nevertheless, Távora also made some significant changes. There was an obvious reformulation of the ruin of the Casa da Eira (Figure 8), where, instead of merely covering the space, he emptied it, introduced a spiral staircase and raised the roof (in-depth transformations with a modern design). There was also an important alteration made in the main house, both in terms of its use and spatial configuration. Távora imagined that this summer house would have an informal, spontaneous way of life, so he decided that the main floor must be an open space in which the kitchen, sitting area, dining room and living room followed on from one another without any partitions. This arrangement represented a break with tradition that was designed to achieve a much more spacious and brighter environment, in which the placement of the furniture, fireplace and windows helped to generate different atmospheres within the same pavilion (Figure 9). However, the bedrooms and the bathroom are located downstairs, taking the place of the old stables, facing the courtyard. The main house was connected via a passageway with the small annex, which is the most private and independent room. In both areas, the ground level had to be lowered in order to gain sufficient headroom.

Here too, the skilful handling of colour was a powerful tool in achieving the unity of the whole project, also highlighting the architect's manipulations of the pre-existing building. Thus, the blood red colour highlights the new joinery of the glazed porch and the increased height of the Casa da Eira. The interior surfaces are almost completely covered in white, helping to generate a continuous, light-filled atmosphere.

\section{COMPARATIVE ANALISYS}

The analysis of the case studies enables us to identify a series of common features (and also diverging nuances) in order to draw some conclusions about Fernando Távora's approach to the renovation of vernacular houses. It should be borne in mind that both the Briteiros and Pardelhas renovation projects were works from the architect's mature period, when he was able to act with knowledge and certainty (even without using any plans), following consolidated methodological guidelines after decades of experience in refurbishment.

The starting point of the design process was the identification of those features that give the pre-existing building a unique identity and authenticity and create a sense of belonging to the place. In Briteiros, Távora found this singularity in the strong historical imprint of the site, which had been inhabited by different peoples since ancient times (Celts, Romans, Muslims...). Furthermore, the importance of the introduction of corn as an agricultural crop was reflected in the structure and organisation of the building. The evolutionary sequence of the building (deduced after scrutinising the walls in search of joints and scars) highlighted its gradual adaptation to productive changes. On the other hand, in Pardelhas, Távora focused on the perfect setting of the house in the landscape, pointing to the patina of the walls and the water that flows through the estate as fundamental elements of the genius loci of the place.

3 Interview with Fernando Barroso (08/27/2019). He finished the work that was started by Pedro Pacheco.
Fernando Távora struggled to rigorously preserve those identifying elements that he considered to have architectural or constructive value, in order to conserve and enhance the "spirit of the place", replacing those missing pieces so that it would work again. With this scope, all structural elements that could be preserved were maintained. Hence, traditional solutions were recovered, and where it was necessary to replace a damaged part or restore a missing gap, clearly distinguishable elements were not inserted, but simplified pieces instead (abstractions from the original ones) that barely reveal the repair work so as not to disturb the perception of the whole, but without falsifying the past. In these situations, Távora creates a kind of "ambiguous atmosphere" between the past and the present, in which an inattentive gaze would not perceive any discontinuity or rupture between the new and the old material.

In general, there were no major problems relating to construction or design, but instead ones that were conceptual in nature, namely how to accept the contradiction implicit in transforming farmhouses into holiday homes for wealthy families, somehow perverting their raison d'être as productive machines intrinsically linked to the exploitation of the surrounding countryside. Távora assumed the possible contradictions, refusing to be constrained by nostalgia, and understood that the pre-existing building was a sort of living entity subject to evolution and successive transformations. In fact, its adaptive reuse was the only alternative for ensuring the survival of its ancient values. He took advantage of this premise to design functional reconversions that nonetheless allowed for an immediate perception of former rural activities, by combining the previous identity with contemporary functions. The duplicities and contradictions inherent in Fernando Távora's architectural approaches, just as in Fernando Pessoa's heteronyms, were compatible and enriched the work as well: "restoration, recovery or reuse is, for Távora, the search for a synthesis that can capture the flow of time and calmly welcome the future" (Costa, 2005).

In this regard, the delicate manipulation of façades shows the skilful balance achieved by the architect. He managed to keep visible "a consolidated historical image of the existing building" (Leoni, 2005), while the slight changes also offer a renovated appearance. Thus, both in Briteiros and Pardelhas, the masonry walls remained almost untouched while the light wooden fences of the porch and the sequeiro were reformulated. So, the new joinery, light fittings, handrails and metalwork were handmade by artisans, following designs, materials and colours that were inspired by traditional models, although reinterpreted (more stylised, slender and refined). Hence, Távora succeeded in creating up-to-date images while continuing to observe the constructive tradition, resulting in both a modern appearance and a pretence of timelessness. He also achieved a great sense of unity in the final result, using, among other resources, simple but effective colour codes to unite the new and old elements.

Philology and accuracy did not, however, inhibit Távora from freely carrying out some in-depth transformations that enabled functional updating, as well as other operations, to improve the conditions of hygrothermal and practical comfort. Hence, at Briteiros, the stables and the barn were compartmentalised to form cosy bedrooms with bathrooms; while, at Pardelhas, the first floor is an open, continuous and bright space that represents a break with the segregation of traditional vernacular spaces. Likewise, the preservation of local techniques and materials does not preclude the use of modern conventional systems, such as reinforced concrete slabs. 
Távora's preference for constructing without plans - what he described as "cane architecture" - freed the architect from adhering to a rigidly pre-established design, thus obtaining greater freedom to alter the initial proposal as the work developed, which allowed for more creativity at the construction site and resulted in greater freshness for the finished work. Moreover, this working system made it possible to get the most out of the expert craftsmen, whose ancestral skills were not based on written instructions, but on their knowledge of the techniques required, the materials to be used and the practical, logical and intuitive resolution of problems on site. However, this greater flexibility also compelled the architect to constantly supervise the construction in order to ensure the unity and coherence of all the works. Even so, some errors also occurred as a result of unforeseen circumstances that were solved spontaneously on site.

\section{CONCLUSIONS}

The renovation projects of vernacular houses implemented by Fernando Távora are valuable examples of an intervention methodology that allowed for the adaptive reuse of rural buildings, responding to the needs of a current lifestyle while respecting their authenticity and powerful identity within the cultural landscape of northern Portugal. These projects were supported by his great sensitivity towards vernacular traditions and his extensive knowledge about rural customs, typologies and traditional construction systems that, together with his vast erudition in history and art, provided a solid cultural foundation.

His conservation and renovation design methodology was based, on the one hand, on a careful analysis of history and landscape to find the most authentic values of the building that should be preserved and enhanced; on the other hand, some parts had to be carefully altered in order to achieve an effective functional adaptation. Távora managed to update the image of the building through a creative reinterpretation of tradition, achieving final results of great harmony between the new and old through apparently anonymous, but subtle, modern interventions. Following the principle of "continue innovating", Távora shows that "heritage cannot only mean what our ancestors (...) have left us (...) [but it also consists of] a permanent and collective creation" (Ferrão, 1993).

The new creation, although firmly rooted in vernacular construction, is no stranger to classical compositional mechanisms (balance, proportion, rhythm...). Somehow, he tried to synthesise multiple influences into a universal language with the alphabet of local tradition. Likewise, Távora's respect for tradition was not opposed, but instead complementary, to modern approaches since "he transformed fidelity [to the Modern Movement] into an inclusive and non-exclusive attitude. Hence, the continuity and coherence, and, above all, his permanent modernity" (Costa, 2005).

\section{ACKNOWLEDGEMENTS}

This work is part of the doctoral research that the first author is developing, thanks to a $\mathrm{PhD}$ scholarship awarded by the University of the Basque Country UPV/EHU. The work is also funded by the FCT (Foundation for Science and Technology), project UIDB/00145/2020. We are grateful for the collaboration of the Marques da Silva Foundation Institute (FIMS). We are also indebted to the kindness of those who provided us with information and facilitated access to the case studies.

\section{REFERENCES}

Alves, T. R. C, 2019: Memória como oportunidade. O processo de reinterpretação da Casa da Quinta da Cavada de Fernando Távora (Master's Degree Thesis). Universidade do Minho.

Costa, A. A., 2005: Quando o patrimônio é a casa do vilão. Alexandre Alves Costa: candidatura ao prémio Jean Tschumi, Prize Nominee, UIA 2005, 80-85.

Cotter, A. B., 2013: Casa em Pardelhas: o desenho de Fernando Távora na Arquitectura Popular, n.d.

Fernandes, E., 2019: The construction of the Porto School. Structures and Architecture. Structures and Architecture. Bridging the Gap and Crossing Borders, CRC Press/Bakema, London, 1017-1023.

Ferrão, B. J., 1993: Tradition and modernity in the work of Fernando Távora, 1947/1987. Fernando Távora. Blau, Lisbon.

Ferreira, T., 2007: Sulla storia del restauro in Portogallo: provvedimenti, protagonisti, interventi. Anake: cultura, storia e tecniche della conservazione, 52, 78-95.

Goodwin, P. L., 1943: Brazil builds; architecture new and old, 1652-1942. The Museum of Modern Art, New York.

Leal, J., 2009: Arquitectos, engenheiros, antropólogos: estudos sobre arquitectura popular no século XX português. Fundação Instituto Marques da Silva, Porto.

Leoni, G., 2005: Oltre il "moderno": l'architettura di Fernando Távora. Fernando Távora: opera completa. Electa, Milan.

Mourão, Â.M.C., 2013: A reabilitação como procura de uma identidade. Através de duas obras do Arquitecto Fernando Távora. A Casa da Quinta da Cavada e a Casa de Pardelhas (Master's Degree Thesis). Universidade do Porto.

Ordóñez-Castañón, D., Cunha-Ferreira, T., Sánchez-Beitia, S., 2019: Towards a new approach of architectural heritage intervention in Portugal: Fernando Távora and the refurbishment of the Casa da Igreja of Mondim de Basto (19581961). WIT Transactions on the Built Environment, 191, 187198. doi.org/10.2495/STR190161.

Sindicato Nacional dos Arquitectos, 1962: Arquitectura Popular em Portugal. Sindicato Nacional dos Arquitectos, Lisbon.

Távora, F., 1945: O problema da casa portuguesa. Aléo 9, 10.

Távora, F., 1964: Da organização do espaço. FAUP Publicações, Porto.

Távora, F. 1985: Pousada de Santa Marinha de Guimarães. Boletim da DGEMN, 130.

Távora, F., 1990: Discurso sobre Arquitectura \#1: Arquitecto Fernando Távora (lecture, 17/01/1990). FAUP, Porto.

Távora, F., 1993: Casa de Férias em Briteiros, Guimarães, 1989-1990. Fernando Távora. Ed. Blau, Lisbon, 160-165. 